University of Nebraska - Lincoln

DigitalCommons@University of Nebraska - Lincoln

H. W. Manter Laboratory Library Materials

$12-1915$

\title{
Notes on the Trematode Genus Telorchis with Descriptions of a New Species
}

Horace Wesley Stunkard

University of Illinois

Follow this and additional works at: https://digitalcommons.unl.edu/manterlibrary

Part of the Parasitology Commons

Stunkard, Horace Wesley, "Notes on the Trematode Genus Telorchis with Descriptions of a New Species" (1915). H. W. Manter Laboratory Library Materials. 10.

https://digitalcommons.unl.edu/manterlibrary/10

This Article is brought to you for free and open access by DigitalCommons@University of Nebraska - Lincoln. It has been accepted for inclusion in H. W. Manter Laboratory Library Materials by an authorized administrator of DigitalCommons@University of Nebraska - Lincoln. 


\section{NOTIS ON THE TREMATODE GENUS TELORCHIS WITH DESCRIJTIONS OF NEW SPECIES*}

\section{Horace II. STIN Kard}

In 1889 I. uhe created a new genus, Tolurchis, to contain certain reptiliat distome parasites, and designated $I)$. claz'd Diesing (1850) as the type species. In the genus he included D. poiricri stoss. $(=D$. gclatinosum l'oirier nec. Rud. ), D. linstori Stoss. (= Monostomum aculcatum v. Linst.), I). ercolanii Montic. (=D). signatum Ercol. nec. Duj.), D. nematoides Mïhl., D. bifurcum Braun, D. pleroticum Braun, and tentatively D. arrectum Mol. nec. Duj. His characterization of the genus states that the testes lie behind one another at the posterior end of the body; the cirrus sac opens somewhat left of the acetabulum and is rery long: the ovary is immediately behind the posterior end of the cirrus sac and is separated from the testes by the coils of the well developed uterus; while the vitellaria consist of numerous follicles occupying the space at the sides of the body and approaching more or less closely the anterior and posterior ends. The diverticula of the intestine reach almost to the posterior end of the body; and with the exception of $D$. poiricriall species are armed with spines at the cephalic extremity of the worm. The excretory vessel is long and branches anteriorly in the form of a $Y$. The oral sucker is usually slightly larger than the acetabulum, though in $D$. crolanii of the same size.

This same group of reptile distomes was separated by Looss (1899) independently, and also called Telorchis, but his article appeared after that of Lühe. Looss selected D. linstozin as the type species.

Because of the differences existing between $T$. claz'a and the other memlers of the genus, Lühe later (1900) created two sulggenera: Telorchis with $T$. clar'a as type, and (ercorchis with T. aculeatus $(=T$. linstorit Stoss.) as the type. The distinguishing features of the subgenus Tolorchis are stated as the absence of an esophagus and the lateral extension of the folds of the uterus beyond the diverticula of the intestine where they may be coiled over the ceca in the form of a figure 8. In the sub-genus Corcorchis an esophagus is present and the coils of the uterus are confined between the ceca.

My examination of almost a hundred mature individuals of six different species affords evidence that the lateral extension of the uterus varies largely ats a result of congestion with eggs. In the same species one finds some specinens in which the coils of the uterus are confined

* Contributions from the Zoological Lahoratory of the University of Illinois, uncler the direction of Henry B. Ward, No. 55. 
between the cea and others in which the uterine folds overlap the diverticula on one or both sides. Certain species in the genus possess a long esophagus, others a short esophagus, and finally in $T$. claz'a an esophagus is absent. Furthermore the absence of an esophagus is not always associated with an extracecal coiling of the uterus, and vice versa, since in $T$. bifurcus an esophagus is absent and the uterine coils are intracecal, and in $T$. corti an esophngus is present and the uterine folds often overlap the ceca. These facts show that the character: designated by Liihe are not adequate to subdivide the genus, and since the apparent morphological differences of his types are merely extreme variations of characters common to several species, the sub-genera disappear.

Goldberger (1911) described as new species T. stossichi, T. attenuatus and $T$. robustus, and formulated a key for the identification and separation of the species.

The genus has a wide distribution, species having been reported from Sicily, Sardinia, Italy. France, Germany, Austro-Ilungary, Turkey, Brazil, Lnited States and Canada. So far as is known it is confined to reptilian hosts, species occurring in lizards, snakes and turtles.

The trematodes in this genus are elongate, with more or less parallel sides. The region of greatest width is at or anterior to the middle of the body. They range in length from 1.5 to $13 \mathrm{~mm}$. and in width from 0.25 to $1.6 \mathrm{~mm}$. In $T$. arrectus the ratio of width to length is $1: 4$, in $T$. diminutus it is $1: 5$, in $T$. clar'a. $T$. bifurcus and $T$. lobosus it is about $1: 7$, while in $T$. pleroticus it is $1: 18$ and in $T$. poiricri it is $1: 22$. That part of the body between the oral sucker and the acetabulum is much more motile than the post acetabular region, which is essentially a sac containing the reproductive apparatus.

The cuticula is of uniform thickness in any one worm; it varies from $2 \mu$ in $T$. parzus and $T$. diminutus to $11 \mu$ in $T$. attenuatus, the thicker cuticula being found in the larger species. Cuticular spines occur on the bocly arranged in a quincunx pattern and around the external openings in concentric circles. They are deeply imbedded in the cuticula which is raised about the base of each spine in a papilla like structure. Largest around the oral sucker, they gradually diminish in size toward the posterior end of the body where they are indistinct or entirely absent. The rows are separated by distances slightly exceeding the length of the spines. In general, the spines vary in size and proximity directly with the size of the worm. In one specimen of $T$. robustus $13 \mathrm{~mm}$. long, the spines near the anterior end are $6.5 \mu$ apart and $5.7 \mu$ in length, and in another $6 \mathrm{~mm}$. long they are $3.2 \mu$ apart and $3 \mu$ in length. In specimens of $T$. lobosus they are $2 \mu$ long and in rows 
$2.2 \mu$ apart, and in $T$. diminutus they are $1.5 \mu$ long and in rows $1.6 \mu$ apart. The cuticula turned in at the external openings is not spinous.

The musculature of the body (Fig. A) is light and delicate so that the worms are translucent.

The excretory system is typical for the genus. The pore is situated at the posterior tip of the body and opens from a large, median collecting duct (Fig. B) which extends anteriorly to about the location of the ovary; there it divides into branches that extend anteriad, one on either side of the median line, just mesal to the intestinal diverticula. These branches can be traced almost to the region of the acetabulum where they disappear. In studying living specimens of $T$. cort $i \mathrm{I}$ have been able to distinguish the flame cells, but their ducts could not be followed.

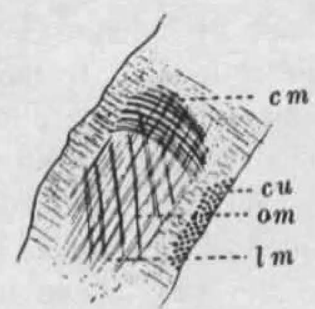

Fig. A

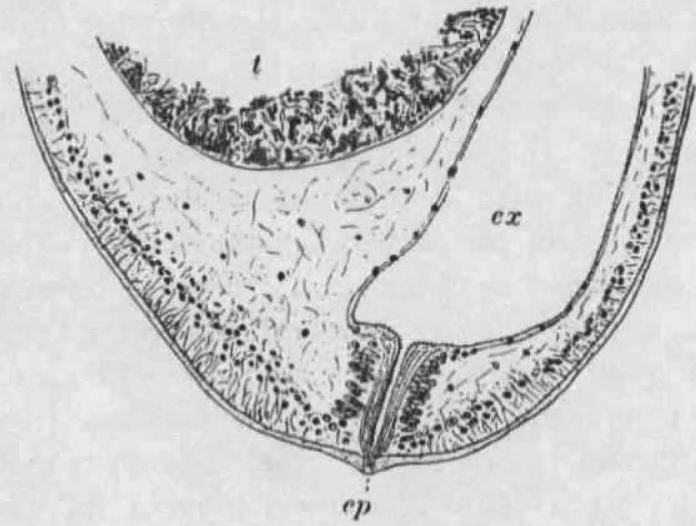

Fig. B.

Fig. A. Tangential section of body wall in $T$. lobosus, showing muscle layers and cuticular spines; $c u$, cuticula ; $c m$, circular muscles; $l m$, longitudinal muscles; om, oblique muscles.

Fig. B. Sagittal section at median posterior end of body in $T$, robustus, $e p$, excretory pore; $e x$, collecting duct of excretory system; $t$, caudal testis.

The oral sucker is sub-terminal in position, equalling or slightly exceeding the acetabulum in size. The shape of both the oral sucker and acetabulum is subject to considerable variation as can be observed by watching the movements of a living worm. The shape of the sucker at the time of killing and the character of the reagents used influence the shape of the organ in the fixed material, although there seems to be a certain relation between the general shape of the sucker and the species.

A prepharynx is absent in $T$. aculeatus and T. nematoides and in some forms can be noted only when the cephalic extremity of the worm is much extended. All degrees of variation in length occur to a distinct 
and elongated pouch in $T$. bifurcus and $T$. pleroticus. The pharynx is approximately spherical although either the longitudinal or transverse diameter may be greater. An esophagus is absent in $T$. claz'a and in $T$. pleroticus, short in $T$. aculcatus and $T$, parzus, and very long in $T$. medius and $T$. soliz'agus. The ceca meet anteriorly at an acute angle and extend almost to the posterior end of the body, terminating rarely ( $T$. parz'us and $T$. poirieri) in the inter-testicular zone, and in all other known species behind the caudal testis. Anterior to its bifurcation the digestive tract is lined with cuticula continuous with that of the external surface, and the ceca are lined with digestive epithelium, cells with nuclei close to the fibromuscular wall and cytoplasmic processes extending into the lumen of the canal. If the contents of the ctca are forced caudad the ends may be bulbous or flask!ike in appearance, while if the caudal part of the excretory duct is much distended the ceca must necessarily taper gradually.

The testes lie in close proximity, one behind the other near the posterior end of the body, in the median line or slightly to the right and left. In his description of T. parz'us, Braun (1901) states that due to the flattened condition of the body the collecting duct of the excretory sy'stem passes between the testes in the shape of a letter $S$ so that when it is distended it causes the testes to lie obliquely. In most cases the excretory duct is dorsal to the testes and conditions are not those in $T$. parrus. The vasa efferentia pass cephalad, just median to the ceca, the duct from the cephalic testis on the left and that from the caudal testis on the right. The ducts move mediad and dorsad as they pass forward; at the region of the ovary they pass above the excretory tubes and then on the median side of these tubes to the posterior end of the cirrus sac where they empty into the vesicula seminalis. The cirrus sac (Fig. 1) is a long, cylindrical, muscular pouch extending caudad from the genital pore and enclosing the cirrus, vas deferens, prostate, and seminal vesicle. The genital pore is immediately anterior and at the left of the acetabulum. In one specimen of $T$. corti the cephalic testis had divided, the resulting organs lying one on either side of the median line. This specimen was not sexually mature and the vasa efferentia could not be traced.

The ovary is in or near the median line, posterior to the acetabulum, and usually just anterior to the center of the body. The oviduct arises from the dorsal posterior margin and after one or two slight irregularities it enlarges to form the ootype which is surrounded by the large unicellular glands of the shell gland. Figure 7 shows the structures of the female genital system in the vicinity of the ovary. Laurer's canal branches from the dorsal posterior part of the ootype and opens on the dorsal surface; the common vitelline duct enters the ootype just 
ventral to and at the left of the origin of Laurer's canal. In some species the proximal end of Laurer's canal is enlarged to form a seminal receptacle and in $T$. aculeatus the enlargement may comprise the entire tube which in one case was filled with chromatin granules, in other instances no enlargement is present, as in $T$. robustus. The uterine tube turns first ventrad and then begins a series of irregular, sinuous convolutions, extending posteriad to the cephalic testis and returning anteriad to the nearly straight metraterm which leads to the common genital sinus. The opening of the metraterm is anterior and at the left of the opening to the cirrus sac. The descending and ascending coils of the uterus occupy separate distinct fields in $T$. aculcatus and $T$. parz'ts; in $T$. bifurcus they overlap and are in some cases indistinct, while in $T$. dimimutus and $T$. nematoides they are so superimposed and confused that only rarely can distinct fields be discerned. In $T$. soliz'agus Odhner (1902) reports that the descending and ascending limbs of the uterus cross each other to fon a figure 8 and other authors mention this crossing or absence of crossing as a specific character, but in $T$. corfi hoth conditions exist.

The vitellaria lie laterad of the ceca, and consist of a large number of follicles, usually arranged in lobes. Typically there are nine lobes on the right and twelve lobes on the left side of the body, although there is considerable variation from this condition. There is a tendency for the lobes to fuse, reducing the number, and the vitellaria of the left side extend farther cephalad and coudad than those of the right. In $T$. aculeatus the lobes are distinct, in most of the species they can be distinguished, while in others ( $T$. diminutus and $T$. rolustus) the vitelline follicles are not separated into lobes but extend along the sides in an unbroken seties. I.ongitudinal collecting ducts occupy the median face of the vitellaria, and in the region of the ootype short ducts leading mediad from these unite near the median line of the body to form the vitelline receptacle from which the common yolk duct leads to the ootype.

In all sexually :nature worms the uterus contains enormous numbers of eggs. They vary in size from 10 by $20 \mu$ in $T$. pleroticus to 22.8 by $40 \mu$ in $T$. parz'us, and 21 by $41 \mu$ in $T$. diminutus. It is interesting to note that in the smallest species, $T$. parr'us and $T$. diminutus, the eggs are larger than in the largest species, $T$. poiricri and $T$, robustus, where they measure only 14 by $23 \mu$ and 15 by $29 \mu$, respectively.

If the description given by Stafford (1900) and (1905) of $T$. angustus, and that by Barker and Covey (1911) of T. Ieptus are confirmed by further study, then these species do not belong in the genus Telorchis as conceived and discussed in preceding section of this paper. The long distance separating the acetabulum and the genital pore, the dorsolateral location of the latter, and the pre-acetabular position of 
the cirrus sac form a complex of such striking and fundamental differences that a natural grouping will remove these forms from the genus Telorchis, therely raising the sub-genus Protenes Barker and Covey to generic rank. Protenes leptus designated by Barker and Covey must be taken as type.

To Professor Henry B. Ward, under whose direction this work was done, I wish to express my appreciation for criticisms and suggestions.

Tolorchis corti sp. nov. (Figs. 1,4)

Specimens 4 to $7.15 \mathrm{~mm}$. long: 0.35 to $0.5 \mathrm{~mm}$. wide; greatest width at acetahulum, which is $0.14 \mathrm{~mm}$. in diameter, one sixtl to one seventh of hody length from anterior end. Oral sucker same size as acctabulum; cuticular spines around former $3.4 \mu$ in length. Pharynx 70 to $80 \mu$ in diameter. Esophagus short, $50 u$ long, $25 \mu$ in diameter. Ovary spherical or slightly oval, in median line or just left of it, alout three eighths of body length from anterior end ; $0.117 \mathrm{ly} 0.147 \mathrm{~mm}$. in the smaller specimens and $0.147 \mathrm{hy} 0.176 \mathrm{~mm}$. in the largest; long axis parallel to that of hody. Receptaculum seminis present; Laurer's canal opens just caudad of ovary. Literus extends posteriad on left side, returning on right, rarely descending and ascending limbs cross about one thire of destance from ovary to ceghalic lestis, forming a ligure is coils of uterus occasionally overlap diverticula through central half of distance from uvary to cephalic testis on one or both sides. Metraterm almost straight. extending caudad from genital pore one fourth to one third of distance to ovary. Vitellaria arranged in lobes; separate lobes often not distinct; begin about one-third of distance from ovary to acetalulum, cephalad of posterior end of cirrus sac; extend about five sixths of distance from ovary to cephalic testis. Twenty to forty follicles in each lohe. Testes spherical or oval, ahout equal in size, 0.2 10 0.2$) \mathrm{mm}$. in length; 0.16 to $0.24 \mathrm{~mm}$. in width: separated hy 0.05 to $0.1 \mathrm{~mm}$. Cirrus sac extends caudad from genital pore three fourths of distance to ovary; 1.12 to $1.18 \mathrm{~mm}$. in length; $0.088 \mathrm{~mm}$. in width. Vas

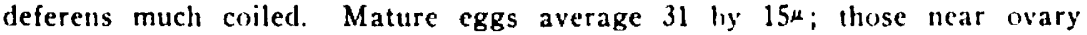
broader, measuring 30 by $19 \mu$.

In my material there are many immature specimens. The young worms are proportionately wider than the adults with the region of greatest width at the pharynx. The smallest mounted measured 0.65 $\mathrm{mm}$. in length and $0.16 \mathrm{~mm}$. in width. In this specimen the oral sucker is $0.085 \mathrm{~mm}$. in diameter and the acetabulum is very small, $0.03 \mathrm{~mm}$. in diameter. The esophagus is longer and the ceca are larger proportionately than in the adult. The cirrus sac, ovary and testes appear merely as masses of heavily staining cells. In a specimen $1.7 \mathrm{~mm}$. long the body is $0.2 \mathrm{~mm}$. in width. The suckers have increased in size, the oral to 0.09 and the acetabulum to $0.063 \mathrm{~mm}$. in diameter. The intestine has acquired the shape characteristic of the adult, the ovary has assumed definite form, the testes have become more prominent, and the cirrus sac is well defined at the anterior end although the posterior end is extended as a line of deeply staining cells reaching to and apparently connected with the ovary. No trace of uterus or vitellaria could be distinguished. 
A comparison of $T$. corti with $T$. aculcatus and $T$. soliz'agus, the species which it most closely resembles, shows that the forms are about the same length; $T$. corti is narrower and thicker than the others. The oral sucker and pharynx are smaller in $T$. corti and the esophagus is shorter. Odhner (1902) says that in $T$. solizagus the descending and ascending limbs of the uterus cross to form a figure 8 ; in $T$. corti both crossed and parallel conditions are present. In $T$. aculeatus and $T$. solizagus the cirrus sac extends from the genital pore caudad to the ovary, in $T$. corti it extends only three fourths of the distance to the ovary. In $T$. aculeatus the lobes of the vitellaria are more separate and distinct than in $T$. corti, and in $T$. soliz'agus they are not definitely arranged. In $T$. aculeatus they do not extend as far anteriad or posteriad as in $T$. corti. The eggs of $T$. corti are about the same size as those of $T$. soliz'agus and smaller than those of $T$. aculeatus.

Some fifty individuals of this species, most of them immature, were found in the intestine of seven specimens of Malacoclemmys lescurii from Newton, Texas. An adult worm was obtained from the intestine of a single specimen of Chryscmys elegans from the same region. The species was also collected in June, 1910, at Havana, Ill., from the intestine of Maluccoclemmys geographicus.

This species was named in honor of Dr. W. W. Cort.

Telorchis lobosus sp. nov. (Fig. 3)

Adults 1.67 to $2.6 \mathrm{~mm}$. in length; 0.27 to $0.37 \mathrm{~mm}$. in width, greatest width near center of body. Acetabulum circular, about two sevenths of total lengtls from anterior end, in mounted specimens from 0.117 to $0.18 \mathrm{~mm}$. in diameter. Pharynx 55 to 633 in diameter. Ovary oval, median, crosswise of the hody, midway hetween anterior and posterior ends; from $401070 \mu$ in shorter and 74 to $85 \mu$ in longer diameter. Small receptaculum seminis present, Laurer's canal passes directly dorsad, opening just above the ovary. Follicles of vitellaria massed together closely; lobes distinguished only at ends of areas. On left side vitellaria extend anteriad about one third of distance from ovary to genital pore, and posteriad alout seven eighths of distance from ovary to cephalic testis. Vitellaria of right side do not extend so far anteriad or posteriad as those on left. Normal eggs measure from 18 by $32 \mu$ to 19 by $36 \mu$. Testes oval, lolulated: their long axis perpendicular to that of worm; from 0.1 by 0.05 to 0.13 by $0.08 \mathrm{~mm}$., very close together but not overlapping in any case. Caudal testis about its own length from posterior end of body. Cirrus sac extends from genital pore caudad to ovary; vas deferens not coiled as much as in $T$. corti.

In size and structure $T$. lobosus agrees most closely with $T$. nematoides, but a comparison with the description of Mühling shows specific differences. The forms are similar in the extent of vitellaria, cirrus sac, and size of eggs; but $T$. lobosus is smaller, shorter and flatter than $T$. nematoides, the suckers and pharynx are smaller, the esophagus is much shorter, and striking differences are noted in the ovary and testes.

Nine worms of this species were obtained from the intestines of two specimens of Chelydra serpentina from Walker, Iowa. 
Telorchis medius sp. nov. (Figs. 2, 7)

Sexually mature worms 3 to $5.28 \mathrm{~mm}$. in length; 0.35 to $0.48 \mathrm{~mm}$. in width; body closely resemhles $T$. corti. At anterior end cuticular spines $2.8 \mu$ in length, in rows $3 \mu$ apart. Acetaluulum one fifth to one fourth of body length from anterior end: in mounted specimens longer than hroad, measuring 0.1 by $0.11 \mathrm{~mm}$. to 0.12 by $0.146 \mathrm{~mm}$. Oral sucker circular or slightly uval, with either diameter greater, varying from 0.115 to $0.146 \mathrm{~mm}$. Slort prepharynx shows in well-cxtended specimens, in sagital sections measuring f(0) in length. Pharynx lioadly oval, 50 to $60 \mu$ long and 60 to $70 \mu$ liroad, followed by long esophagus measuring 0.2 to $0.27 \mathrm{~mm}$. Diverticula extend posteriad to point midway between cautal testis and posterior end of lenty, diameter 12 to $15^{\mu}$. Ovary spherical or broadly wal, median, three sevenths of total length from anteriur end; diameter 0.15 th $0.2 \mathrm{~mm}$. Figure 7 slows relations of female genital apparatus in ovarian region. Vitellaria extend anteriad to point midway between caudal end of cirrus sac and cephalic margin of ovary, and posteriad seven eighths of distance from ovary to cephalic testis; lobes usually distinguishable. Eggs 21 by $43^{\mu}$; near ovary slightly more spherical, measuring $26 \mathrm{ly} 42 \mu$. Testes spherical or oval, 0.185 to $0.25 \mathrm{~mm}$. in diameter. Cirrus sac extends from genital pore caudad four fifths to five sixths of distance to ovary. Vas deferens coiled mure than in $T$. lobosus and less than in T. corti.

$T$. medius shows more morphological similarity to $T$. corti than to any other known species but the differences constitute sufficient ground for separation. T. modius is shorter, more uniform in width, has a much longer esophagus, the cirrus sac extends farther caudad, the acetabulum and ovary are nearer the middle of the body, and the vitellaria do not extend so far anteriad, the eggs are larger, and considering the differences in the size of the worms the ovary and testes are also larger in $T$. medius.

Eleven mature and sixtcen immature specimens were taken from the intestines of three dozen individuals of Aromochelys odoratus from Raleigh, N. C.

\section{Telorchis diminutus sp. nov. (Fig. 8)}

Mature worms 1.2 to $1.5 \mathrm{~mm}$. in length; 0.2 to $0.25 \mathrm{~mm}$. in width. Greatest width in acetabular region. Acetabulum circular or oval, two sevenths of total length from anterior end; 62 to $80 \mu$ in diameter. Oral stcker circular or oval. 75 to $90 \mu$ in diameter; pharynx from 30 to $40 \mu$ in diameter; esophagus 70 to $100 \mu$ in length. Ovary spherical, 60 to $80 \mu$ in diameter, caudal margin midway between anterior and posterior ends of body. Receptaculum seminis present, Laurer's canal about $30^{\mu}$ long, opens immediately caudad of ovary. Descending and ascending limbs of uterus usually interwoven and not in distinct fields. Vitellaria poorly developed, not arranged in lohes, extending from ovary posteriad two thirds to three fourths of distance to cephalic testis. Eggs measure 41 by $20 \mu$. Testes spherical or slightly oval, usually longer in the anteroposterior axis, 58 to $76 \mu$ by 69 to $92 \mu$. Cirrus sac extends posteriad from genital pore almost to region of ovary; very much coiled.

In general structure $T$, diminutus closely resembles $T$. parz'us Braun, but the two species differ in many distinct items. They have approximately the same relative width and correspond closely in position of vitellaria and size of eggs; but $T$. diminutus is smaller, the suckers are larger, the esophagus is shorter, the ceca extend farther 
caudad, the cirrus sac does not extend to the ovary as in $T$. parz'us, and in $T$. diminutus the collecting duct of the excretory system is dorsal to the testes instead of passing between them in the shape of a letter $S$.

These parasites were obtaincd from the intestine of a single specimen of Cinosternum pennsyleanicum from Raleigh, N. C. Some thirty worms were found, about half of which were sexually immature.

$$
\text { Telorihis robustus (ioldberger ( Fig. 6) }
$$

The species was described by Goldleerger in 1911 from a single specimen which was taken from the intestine of Cistudo carolina in Maryland. I have fifteen specimens collected in 1910 from the intestine of Chrysimys digans. A study of these worms affords information which corrects and completes the description of Goldberger. Specimens 6 to $13 \mathrm{~mm}$. in length; 0.8 to $1.3 \mathrm{~mm}$. in width. Acetabulum 0.2 to $0.24 \mathrm{~mm}$. in diameter, located about one fifth of total length from anterior end. Oral sucker usually slightly longer in anteroposterior diameter, 0.25 to $0.28 \mathrm{~mm}$. in the larger specimens. Short prepharynx: pharynx 0.14 to 0.17 in diameter: esophagus short, apparent in wellextended specimens. Testes spherical or sligitly oval, 0.4 to $0.5 \mathrm{~mm}$. in diameter. Female reproductive organs as described by Goldberger except that Laurer's canal opens some distance posterior to the ovary and the vitellaria do not "extend in intercecal areas," hut lie in extracecal margins of hody. Eggs (not mentioned by Goldberger) average 15 by $29 \mu$.

\section{Telurchis aculeatus von Linstow (Fig. 5)}

The material consists of 13 specimens collected from the intestine of Tropidonotus grahamii in June, 1910.

A careful detailed comparison of the worms with the description and figure of T. aculcatus given by Braun (1901) leaves little doubt as to their specific identity and regardless of the wide difference in distribution and host $I$ shall assign the specimens to that species.

\section{SUM MARY}

The study of abundant material, both adult and immature forms from the trematode genus Telorchis, including four species new to science and others from new hosts and localities, has given data for the first general discussion of the genus yet made. The sub-genera Telorchis and Cercorchis proposed by Lühe intergrade and can not be retained. $T$. angustus and $T$. leptus if correctly described should be removed to an independent genus. The new and some older species are discussed in detail.

\section{Liter.sture Cited}

Barker, F. D., and Covey, G. W. 1911. A New Species of Trematode from the Painted Terrapin, Chrysemys marginata Agassiz. Neb. Univ. Stud., $11: 193-218$.

Braun, M. 1901. Trematoden der Chelonier. Mitt. Zool. Mus. Berlin, 2: 13-20.

Goldberger, J. 1911. On Some New Parasitic Trematodes of the Genus Telorchis. Hyg. Lab. Bull., $71: 36-48$. 
Looss, A. 1899. Weitere Beiträge zur Kenntnis der Trematoden-Fauna Aegyptens. Zool. Jahrl., Syst., 12:521-784.

lishe, M. 1899. Zur Kenntnis einiger Distomen. Zool. Anz., 22: 524-539. 1900. Ueber einige Distomen aus Schlangen und Eidechsen. Centr. Bakt., Alt. I, 28:555-560.

N1win. $\mathrm{R}$ 185\%. Nuovi myzelminthi racoulti ed esaminati. Sitz-her. K. Akad. Wiss., Wien, math-naturw. Cl., $37: 818-854$.

Mtuhling, I. I\&;8. Studien aus Ostpreussens Helminthenfauna. Zool Anz. $21: 16-24$.

()dhner, T. 1902. Trematoden aus Reptilien nebst allgemeinen systematischen Bemerkungen. K. Sven. Vetensk-Akad. Förh., 59:19-45.

Stafford, J, 1900. Some L'ndescrilied Trematudes. Zool. Jahrb., Syst., $13: 399-414$

1905. Trematodes from Canadian Vertebrates. Zool. Anz., 28:681-694.

Stossich, M. 1895. I Jistomi dei rettili. Boll. Soc. adriat. sci. nat., $16: 213-293$.

EXPLANATION OF PLATE

ABBREviations

a acetabulum
cs cirrus sac
c esophagus
cp excretory pore
g genital pore
i intestine
I Laurer's canal
"m metraterm
o ovary
od oviduct
os oral sucker

$p$ prostate gland

ph pharynx

$s g$ shell gland

sr seminal receptacle

so' seminal vesicle

$t$ testis

$\boldsymbol{u}$ uterus

$\boldsymbol{v}$ vitellaria

"r vitelline receptacle

vt vitelline duct

All drawings are from canera lucida tracings except Figure 7 , which is from a reconstruction.

Fig. 1.-Terminal section of the genital ducts in $T$. corti, showing cirrus sac and metraterm.

Fig. 2.-T. micdius, ventral view, $x 28$.

Fig. 3.- $T$. lobosus, ventral view, $\times 36$.

Fig. 4.-T. corti, ventral view, $\times 18$.

Fig. 5.-T. aculcatus, ventral view, $x 18$.

Fig. 6.-T. robustus, dorsal view, $x 15$.

Fig. 7.-Female genital apparatus, $T$. medius, from reconstruction of frontal sections, $\times 125$.

Fig. 8. $-T$. diminusus, ventral view, $x 56$. 
PLATE 1

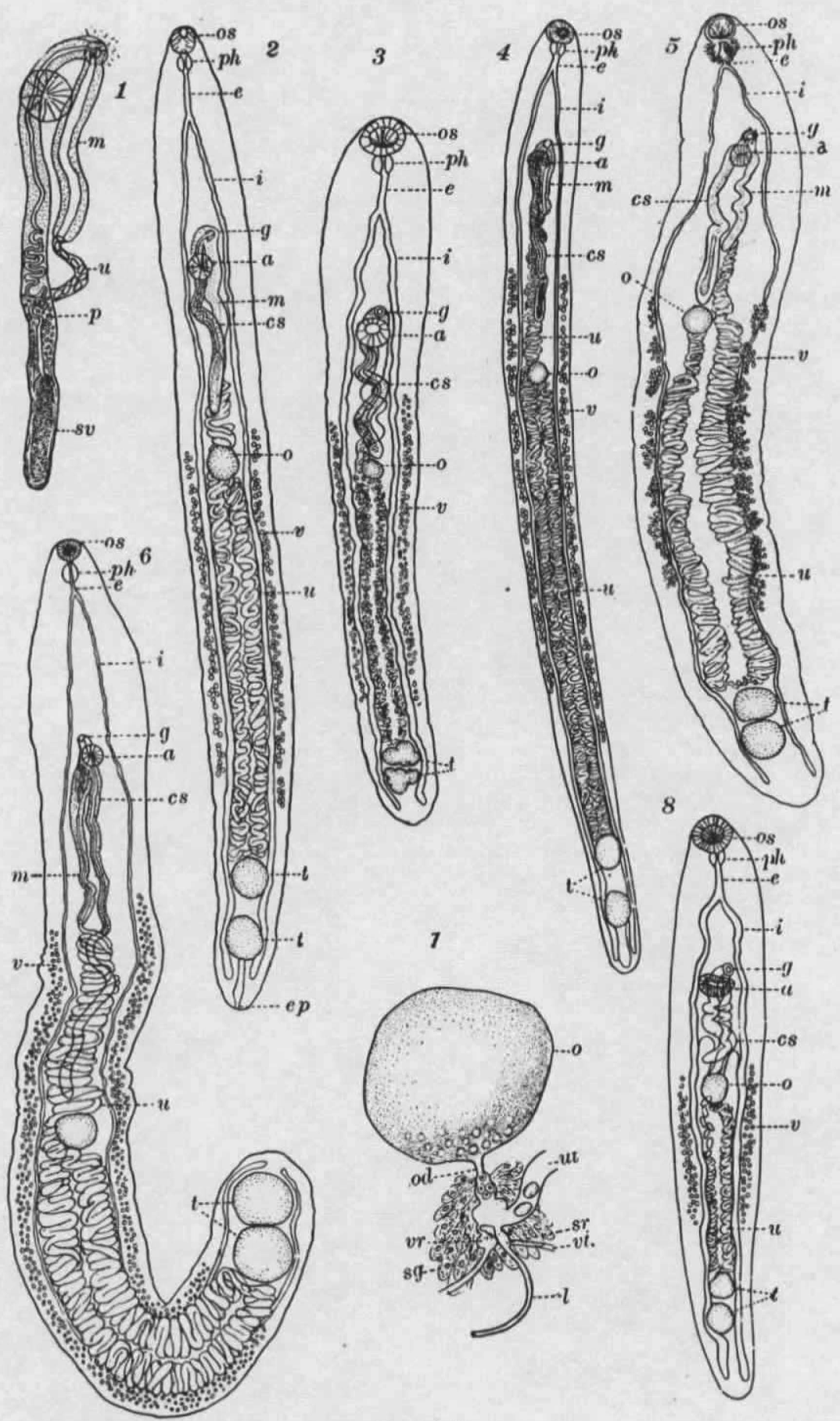

Figs. 1-8 